\title{
Broom snakeweed control and seed damage after herbicide applications
}

\author{
KIRK C. MCDANIEL, BALLARD L. WOOD, AND LEIGH MURRAY
}

Authors are Professor. Dept. Animal and Range Sci., New Mexico State Univ., Las Cruces, N.M. 88003, Res. Asst., Dept. Animal and Range Sci., New Mexico State Univ., Las Cruces, N.M. 88003, and Professor, Experimental Statistics Dept., New Mexico State Univ., Las Cruces, N.M. 88003.

Abstract

Broom snakeweed (Gutierrezia sarothrae [Pursh] Britt. \& Rusby) is a major weed problem in the southwestern U.S. because it is toxic to livestock and suppresses forage productivity. In this study, broom snakeweed control, seed production and viability were determined after broadcast spraying in 1997 and 1998 with metsulfuron (\{2-[[[[(4-methoxy-6-methyl-1,3,5-triazin-2-yl) amino]carbonyl]amino]sulfonyl]benzoic acid\}; $0.03 \mathrm{~kg}$ a.i. ha ${ }^{-1}$ ) and picloram ((4-amino-3, 4, 6-trichloro-2-pyridine-carboxylic acid); $0.28 \mathrm{~kg}$ a.i. ha $\left.^{-1}\right)$. In 1997, plants were sprayed every 2 weeks beginning 1 October when snakeweed was in mid-flower and seed fill and continued until 15 December when seeds were being dispersed. Broom snakeweed control was not different by spray date and averaged $98 \%$ with picloram and $77 \%$ with metsulfuron. Only plants sprayed on 1 October 1997 with either herbicide had significantly less seed viability than nonsprayed plants, but seed production was not different. In 1998, herbicide applications were repeated at 2 week intervals for 6 weeks beginning on 1 September when snakeweed was in early-flower and seed development. Broom snakeweed control with picloram (average $88 \%$ ) was consistently high across all spray dates, whereas, control with metsulfuron (average $25 \%$ ) was always poor. Both herbicides reduced seed production by an average of 99, 95, and 38\% when applied on 1 and 15 September 1998 and 1 October 1998, respectively, but seed production was not different among sprayed and nonsprayed plants after these dates. In the spring of 1999, broom snakeweed seedlings were common in all areas previously sprayed in 1997 , but few seedlings established in plots sprayed in 1998 . In the spring of 2001, the number of newly emerged broom snakeweed seedlings observed in nonsprayed and herbicide-treated areas was the same, irrespective of spray year, herbicide type or date applied. Data indicate that herbicide applications made at flower when seed is in early fill can provide satisfactory plant control and lower seed production. Spraying after seed has reached physiological maturity does not affect seed production or viability. In this study, results were inconclusive for determining if timed herbicide applications in autumn can be used to minimize later broom snakeweed establishment.

Key Words: Gutierrezia sarothrae, reproduction, seed production, seed dispersal, seedling emergence, seed viability, herbicide control, metsulfuron, picloram

\footnotetext{
Manuscript accepted 28 Jan. 02
}

\section{Resumen}

La escobilla de bruja (Gutierrezia sarothrae [Pursh] Britt \& Rusby) es un problema mayor de maleza en el sureste de EU dado que es tóxica para el ganado y porque suprime la producción de forraje. En este estudio, control de la escobilla de bruja, la producción y viabilidad de la semilla se determinaron después de aspersiones en 1997 y 1998 con metsulfuron (\{2-I[I[I(4-methoxy-6metilo-1,3,5-triazin-2-yl) amino] carbonilo] amino] sulfonyl] ácido benzoico\}; $0.03 \mathrm{Kg}$ i.a ha $^{-1}$ ) y picloram (4-amino-3,4,6-tricloro-2piridina-ácido carboxílico); $0.28 \mathrm{Kg}_{\text {i.a }} \mathrm{ha}^{-1}$ ). En 1997, las plantas fueron asperjadas cada 2 semanas empezando en Octubre 1 cuando la escobilla de bruja estaba en media floración y en el llenado de la semilla y continuó hasta Diciembre 15 cuando las semillas fueron dispersadas. El control de la escobilla de bruja no fue diferente por fecha de aspersión y promedió $98 \%$ con picloram y $77 \%$ con metsulfuron. Solamente las plantas asperjadas con cualquiera de los herbicidas en Octubre 1 en 1997 tuvo significantemente menos viabilidad de la semilla que las plantas que no fueron asperjadas, pero la producción de semilla no fue diferente. En 1998, aplicaciones de herbicida fueron repetidas a intervalos de 2 semanas por 6 semanas, empezando en Septiembre 1 cuando la escobilla de bruja estaba en floración temprana y en desarrollo de la semilla. El control de la escobilla de bruja con picloram (promedio $25 \%$ ) fue consistentemente alto a través dé todas las fechas de aspersión, mientras que el control con metsulforon (promedio $25 \%$ ) fue siempre pobre. Ambos herbicidas redujeron la producción de semilla para un promedio de 99, 95, y $38 \%$ cuando se aplicaron en Septiembre 1 y 15 en 1998 y en Octubre 1 en 1998, respectivamente, pero la producción de semilla no fue diferente entre plantas asperjadas y plantas no asperjadas después de esas fechas. En la primavera de 1999, plántulas de escobilla de bruja fueron comunes en todas las áreas previamente asperjadas en 1997, pero pocas plántulas se establecieron en los cuadros asperjados en 1998. En la primavera del 2001, el numero de plántulas de escobilla de bruja recién emergidas observado en áreas sin asperjar y en áreas tratadas con herbicida fue el mismo, indistinto del año de aspersión, del tipo de herbicida o de la fecha de aplicación. Los datos indican que las aplicaciones de herbicida hechas en la flor cuando la semilla esta en Ilenado temprano puede proveer un control de planta satisfactorio y disminuir la producción de semilla. El asperjado después que la semilla ha alcanzado su madurez fisiológica no afecta la producción o la viabilidad de la semilla. En este estudio, los resultados fueron inconclusos en determinar si las aplicaciones de herbicida programadas en otoño pueden ser usadas para minimizar el establecimiento posterior de la escobilla de bruja. 
Southwestern U.S. rangelands with dense infestations of broom snakeweed (Gutierrezia sarothrae [Pursh] Britt. \& Rusby) are often commercially sprayed by aircraft to promote desired grass growth and to prevent potential livestock health problems from this poisonous plant (McDaniel and Duncan 1987, Strickland et al. 1998). The general commercial spray period for broom snakeweed control in New Mexico and west Texas is October through December (Duncan and McDaniel 1991). In the 1980's, about 600,000 ha were sprayed in this region (McDaniel 1989). In the 1990's, partly because of the success of previous broom snakeweed control activities and partly because the plant population naturally declined in many areas, less than half this area was treated. The majority of treated rangeland was aerially sprayed with picloram (4amino-3, 4, 6-trichloro-2-pyridine-carboxylic acid) at a rate of $0.28 \mathrm{~kg}$ a.i. $\mathrm{ha}^{-1}$ whereas less area was treated with metsulfuron ( $\{2-[[[[$ (4-methoxy-6-methyl-1,3,5triazin-2-yl) amino]carbonyl]amino]sulfonyl]benzoic acid\}) at $0.03 \mathrm{~kg}$ a.i. $\mathrm{ha}^{-1}$. These herbicides are typically mixed with water and applied at 140 to 240 liters ha ${ }^{-1}$ total spray volume. According to Sosebee $(1985,2000)$ and Sosebee and Dahl (1991), broom snakeweed increases total nonstructural carbohydrate storage in autumn and this allows herbicides to be more readily translocated to the perennating organs and tissues resulting in optimum plant control.

In New Mexico, commercial aerial applicators usually wait until broom snakeweed completes flowering before spraying (Williams 1990). In its native range from Mexico to Canada, broom snakeweed flowering is photoperiod-sensitive with plants in full bloom earlier and for a shorter duration in northern latitudes (near mid-July) than in southern regions (early September) (Sterling et al. 1999). In New Mexico, broom snakeweed typically begins to flower about 2 weeks earlier in northern portions of the state than southern parts. A study by Wood et al. (1997) closely followed broom snakeweed flower and seed production in central New Mexico and reported that most plants were in full bloom by mid-August and that seed required 6 to 8 weeks to ripen within the inflorescence before dispersal commenced, roughly in mid-October. In the Wood et al. (1997) study, about half the seed dropped to the surface before January and the remainder disseminated by early spring except for a few seeds that were retained within the inflorescence until the next season.
Broom snakeweed relies on seed production for propagation and the number of seeds produced per plant is highly variable depending on plant age, interspecific competition, and seasonal growing conditions (Solbrig 1960, Sterling et a1. 1999). Broom snakeweed germination is erratic from year to year, but when specific environmental conditions are met, then prolific propagation occurs, usually in the spring (McDaniel et al. 2000). Broom snakeweed seedling mortality is often high the first year, but surviving propagules generally live for 7 years or longer (Pieper and McDaniel 1989).

Economic returns from broom snakeweed control depend partially on adult plant mortality and the length of time the sprayed area remains weed free (Torell et al. 1989). Uncertainty about future broom snakeweed establishment limits the potential for economic control (Torell et al. 1992). A survey of 65 New Mexico landowners who paid to spray broom snakeweed in the 1980's indicated that $91 \%$ of the treatments provided satisfactory initial control (Williams 1990). However, because broom snakeweed reestablished on many areas within 5 years of spraying, only half of those surveyed indicated they would use chemical treatments again (Townsend 1995). Commercial spraying in New Mexico in the 1980's was always conducted when broom snakeweed was in the post-bloom stage (mainly in November and December). Evidence from the rancher surveys (Williams 1990, Townsend 1995) suggested that while herbicide spraying is usually effective in eliminating the current crop of mature broom snakeweed plants, there remains uncertainty regarding treatment effects on later seed germination and plant establishment. Thus, in this study, our objectives were to determine: (I) if picloram and metsulfuron treatments provide consistent broom snakeweed control throughout the autumn spray season, (2) if herbicide treatments damage seed production or seed viability, and (3) if herbicide applications can be timed so as to eliminate parent plants and potential seed progeny.

\section{Materials and Methods}

\section{Study Area}

Field experiments were initiated in 1997 and 1998 on the New Mexico State University Chihuahuan Desert Rangeland Research Center (CDRRC) about $35 \mathrm{~km}$ north of Las Cruces, N.M. $\left(32^{\circ} 34^{\prime} \mathrm{N}\right.$, $\left.106^{\circ} 56^{\prime}\right)$. The CDRRC is located on the west mesa of the Rio Grande valley at an elevation of 1,219 m. The experimental site was located on level terrain within a pasture that was lightly grazed with cattle in late winter both years of this study. Rainfall is most common from July through September and averages $236 \mathrm{~mm}$. Low precipitation, warm summers, and mild winters characterize the arid continental climate.

Soils, to a depth of $1.5 \mathrm{~m}$, have sandy loam to sandy texture and are grouped in the Berino-Dona Ana Association (USDA-SCS 1980). Because of eolian origins, these soils are vulnerable to wind erosion leading to constantly shifting coppice dunes throughout the area. Vegetation on the experimental area was once dominated by black grama [Bouteloua eriopoda (Torr.) Torr.J, but is now predominantly broom snakeweed with occasional mesquite (Prosopis glandulosa Torr.). Common grass and forb species include black grama, dropseeds (Sporobolus spp.), three-awns (Aristida spp.), fluff grass [Dasyochloa pulchella (Kunth) Steudel], globe mallow (Sphaeralcea spp.), leatherweed croton (Croton corymbulosus Engelm.), spectaclepod [Dimorphocarpa wislizenii (Engelm.) Rollins], and plains cryptantha [Cryptantha crassisepala (Torr. and Gray) Greene]. Mature broom snakeweed were estimated to be at least 3 years old and plant density across the study area ranged from 3 to 7 plants $\mathrm{m}^{-2}$.

\section{Experimental Design and Herbicide Applications}

The experimental design was a randomized complete block with an augmented factorial arrangement of treatments replicated 3 times. Experiments conducted in 1997 and 1998 were evaluated separately. Factor A consisted of picloram at a rate of $0.28 \mathrm{~kg} \mathrm{a} . \mathrm{i} \mathrm{ha}^{-1}$ and metsulfuron at a rate of $0.03 \mathrm{~kg}$ a.i. ha $\mathrm{h}^{-1}$. Picloram was selected because it is the predominant chemical used by commercial aerial applicators for broom snakeweed control in New Mexico. Metsulfuron is presently more expensive than picloram, but is used as an alternative herbicide choice. Factor B included the picloram or metsulfuron application dates presented in Table 1. In 1997, herbicide applications were made 1 and 15 October, November, and December when broom snakeweed phenology ranged from mid flower and seed fill to post flower and seed dispersal. Partially because of treatment effects noted from the 1997 experiment, the herbicide application schedule was moved ahead 1 month for the 1998 experiment. Thus, in 1998, herbicide 
Table 1. Application date, timing, and spray conditions for 2 herbicide experiments conducted to control broom snakeweed at the Chihuahuan Desert Rangeland Research Center, Las Cruces, N.M.

\begin{tabular}{llcccc}
\hline \hline & & Air & Soil \\
Application Date & Application Timing & Relative & $\begin{array}{c}\text { Wind } \\
\text { Temp }\end{array}$ & Humidity & Speed \\
\hline & & $\left({ }^{\circ} \mathrm{C}\right)$ & $\left({ }^{\circ} \mathrm{C}\right)$ & $(\%)$ & $\left(\mathrm{m} \mathrm{sec}^{-1}\right)$ \\
1997 & & & & \\
1 Oct. & Mid flower - mid seed fill & 23 & 21 & 51 & 0 \\
15 Oct. & Late flower - late seed fill & 21 & 20 & 20 & 0 \\
1 Nov. & Late flower - seed mature & 20 & 13 & 31 & 0 \\
15 Nov. & Post flower - seed dispersal & 14 & 4 & 40 & 3 \\
1 Dec. & Post flower - seed dispersal & 8 & 8 & 75 & 3 \\
15 Dec. & Post flower - seed dispersal & 6 & 2 & 38 & 0 \\
1998 & & & & & \\
1 Sep. & Early flower - initial seed set & 21 & 18 & 32 & 0 \\
15 Sep. & Mid flower - early seed fill & 22 & 22 & 40 & 3 \\
1 Oct. & Mid flower - mid seed fill & 21 & 18 & 34 & 0 \\
15 Oct. & Late flower - late seed fill & 17 & 16 & 33 & 3 \\
1 Nov. & Post flower - seed mature & 16 & 10 & 43 & 2 \\
15 Nov. & Post flower - seed dispersal & 17 & 8 & 34 & 2 \\
\hline
\end{tabular}

applications began on 1 September when broom snakeweed was in early flower and initial seed set and continued, as presented in Table 1, every 2 weeks for 6 weeks when seeds were being dispersed. A nontreated control was included for comparison.

The potassium salt of picloram and the dry flowable formulation of metsulfuron were applied with a $\mathrm{CO}_{2}$ pressurized hand held sprayer (3.3-m boom) delivering 200 liters $\mathrm{ha}^{-1}$ at $400 \mathrm{kPa}$ to 30 - by 30 -m plots. The rates were consistent with the recommended commercial application rates of $0.28 \mathrm{~kg}$ a.i. $\mathrm{ha}^{-1}$ for picloram and $0.03 \mathrm{~kg}$ a.i. ha ${ }^{-1}$ for metsulfuron (Duncan and McDaniel 1991). Application dates, broom snakeweed flower and seed development stages, and environmental conditions during spraying in 1997 and 1998 are given in Table 1. Broom snakeweed control was visually estimated by 3 observers comparing treated plots to non-treated rangeland approximately 12 months after treatment (MAT). The data were analyzed separately by experimental year to compare 3 treatments, 3 replications, and 6 spray dates using the GLM procedure of SAS (1989). Data for both experiments were subjected to analysis of variance and means were separated using Fisher's Protected L.S.D. test at the 0.05 level of probability. When significant herbicide by application timing interactions were not detected, data were averaged across herbicide type.

\section{Seed Production}

Before experiments commenced in 1997 and 1998, relatively uniform sized mature broom snakeweed plants in each experimental plot were randomly selected and marked with different colored pin flags for later seed harvest from the inflorescence. Pin flags in each plot marked 2 plants ( 3 replications; 6 total) that were scheduled for seed collection as follows: at spraying and 2, 4, 6, 8, and 10 weeks after spraying. On each collection date, non sprayed plants (6 total) from untreated plots were also harvested. To facilitate seed cleaning, the outer perimeter of each plants canopy containing mostly flower material was clipped and placed separately in paper bags and transported to the laboratory to dried flower material was first hand threshed to shatter achenes (seed) from capitula and to detach the inflorescence from stems. The sample was then sieved with a No. 7 Clipper screen and the remaining sample (fine litter, capitula, and seed) was pulsed twice in a seed scarifier to break apart capitula and to continue dislodging seed. Seeds were separated from litter using 1.18 and $0.6 \mathrm{~mm}$ mesh screens, respectively. Finally, remaining chaff was separated from seed using a No. 120 Seedburo. The number of seeds in a $0.2 \mathrm{~g}$ subsample of the seed fraction was counted and extrapolated to estimate total seed obtained from the inflorescence. Differences in seed number per plant over the various collection dates and herbicide treatments were analyzed as a completely randomized design with rep by sample date by plant as the error term.

To monitor seed dispersal throughout the duration of each experiment, 2 mature broom snakeweed plants were randomly selected in every experimental plot and a 5 - by 25 - by $51-\mathrm{cm}$ plastic collection tray (trap) was placed in each plant's seed shadow. Trays were covered with stucco wire to retain seed in the trap and small holes were perforated in the tray bottom to be oven dried for 24 hours at $50^{\circ} \mathrm{C}$. The allow rain water to escape using a procedure similar to that described by Wood et al. (1997). Collection of dispersed seed coincided with collections from the inflorescence. All flower material in each trap was emptied into separately labeled paper bags and returned to the lab to be ovendried and cleaned using the procedure described above. Seeds were counted to determine the number in each trap, and then stored for viability testing.

\section{Seed Viability}

Viability tests were conducted shortly after mature seeds were collected from the inflorescences and traps using tetrazolium (TZ) analysis procedures similar to those described by Thill et al. (1985). A subsample of 40 (1997) or 50 seeds (1998) per plant (24 plants per spray date plus controls) were removed from collected material using forceps. If the seed collapsed under normal pressure necessary to pick it up, it was considered immature or deteriorated (fruitless) and not included in the subsample. Seeds were placed in a $5-\mathrm{cm}$ petri dish on double filters saturated with deionized water and imbibed for a minimum of 4 hours. With a dissecting scope, seeds were examined and those with an embryo were dissected near the apical end, below the pappus, and placed in a $1 \%$ aqueous solution of TTC (2,3,5-triphenyl tetrazolium chloride) for 8 hours (Tetrazolium Committee of Association of Official Seed Analysts 1970). Following the soaking period, seed with acceptable red-stained embryos were used to calculate percentage net viability (viable seed/total in TZ test X 100). According to analysis of variance, there was no significant difference in the viability of seed collected from either the inflorescence or dispersed in traps by sample date within an experimental year. Therefore, data from both collection procedures were combined by experiment to compare treatment differences for final analysis. Analysis of variance and L.S.D. procedures in SAS (1989) were used to determine viability differences among spray dates and herbicide treatments by experimental year.

\section{Seedling Numbers}

Broom snakeweed seedlings were counted in June 1998, 1999, 2000, and 2001 using five, 31.5 by $61 \mathrm{~cm}$ permanently marked quadrats located in each experimental plot. These quadrats were placed along 2 diagonal lines across each plot from corner to opposite corner. This allowed a comparison of seedling density after autumn spraying with picloram or 
Table 2. Broom snakeweed control, average seed production, and seedlings established in experimental plots sprayed with 2 herbicides in 1997 at the Chihuahuan Desert Rangeland Research Center, Las Cruces, N.M.

\begin{tabular}{|c|c|c|c|c|c|c|c|c|c|}
\hline \multirow{2}{*}{$\begin{array}{l}\text { Spray } \\
\text { Date }\end{array}$} & \multirow[b]{2}{*}{ Application Timing } & \multicolumn{2}{|c|}{ Plant Control $^{1}$} & \multicolumn{2}{|c|}{ Seed Production } & \multicolumn{2}{|c|}{1999 Seedlings $^{2}$} & \multicolumn{2}{|c|}{2001 Seedlings $^{3}$} \\
\hline & & Picloram & Metsulfuron & Picloram & Metsulfuron & Picloram & Metsulfuron & Picloram & Metsulfuron \\
\hline & & \multicolumn{2}{|c|}{ - } & \multicolumn{2}{|c|}{---(no. plant $\left.{ }^{-1}\right) \cdots$} & \multicolumn{2}{|c|}{ (no. $\left.\mathrm{m}^{-2}\right)$} & \multicolumn{2}{|c|}{ - no. $\left.\mathrm{m}^{-2}\right)$} \\
\hline 1 Oct. & Mid flower - mid seed fill & $100 a^{4}$ & $81 \mathrm{~b}$ & 5034 & 5172 & $11.1 \mathrm{a}$ & $9.3 \mathrm{a}$ & 4.3 & 3.6 \\
\hline 15 Oct. & Late flower - late seed fill & $94 \mathrm{ab}$ & $84 \mathrm{~b}$ & 4623 & 4368 & $40.2 \mathrm{c}$ & $16.5 \mathrm{a}$ & 2.9 & 2.2 \\
\hline 1 Nov. & Post flower - seed mature & 97 a & $93 \mathrm{ab}$ & 3112 & 4546 & $34.8 \mathrm{bc}$ & $35.9 \mathrm{bc}$ & 2.5 & 5.7 \\
\hline 15 Nov & Post flower - seed dispersal & 99 a & $79 \mathrm{bc}$ & 6326 & 4309 & $25.1 \mathrm{~b}$ & $49.9 \mathrm{~cd}$ & 1.1 & 4.7 \\
\hline 1 Dec. & Post flower - seed dispersal & $100 \mathrm{a}$ & $62 \mathrm{c}$ & 4177 & 5724 & $37.3 \mathrm{c}$ & $61.0 \mathrm{~d}$ & 2.5 & 5.0 \\
\hline 15 Dec. & Post flower - seed dispersal & $100 \mathrm{a}$ & $65 \mathrm{c}$ & 3735 & 3627 & $21.5 \mathrm{~b}$ & $24.0 \mathrm{~b}$ & 4.3 & 3.2 \\
\hline Control & & \multicolumn{2}{|c|}{$0 \mathrm{~d}$} & \multicolumn{2}{|c|}{$5421 \mathrm{n} / \mathrm{s}$} & \multicolumn{2}{|c|}{$14.7 \mathrm{a}$} & \multicolumn{2}{|c|}{$4.2 \mathrm{n} / \mathrm{s}$} \\
\hline
\end{tabular}

Plant control evaluated 1 Oct. 1998.

${ }^{2}$ Seedlings counted on 1 July 1999.

${ }^{3}$ Seedlings counted on 1 May 2001

${ }^{4}$ Means within a category with the same letter are not different $(P<0.05) ; n / s$, not significantly different.

metsulfuron in 1997 or 1998. No seedlings emerged in 1998 and 2000; thus, only 1999 and 2001 data are reported. Analysis of variance and L.S.D. mean separation tests were used to determine seedling differences among spray dates, herbicide treatments, experimental years, and collection times.

\section{Results and Discussion}

\section{Broom Snakeweed Control}

It is difficult to determine precisely when broom snakeweed succumbs to a herbicide after autumn spraying because the plant naturally dies back to its woody base when winter dormant. Typically, broom snakeweed shows epinasty and other effects from picloram within 10 days of herbicide application, but recognizable metsulfuron symptoms may take a month or more (McDaniel and Duncan 1987). An accurate evaluation of broom snakeweed control is best made 9 or more months after herbicide application (Sosebee 1985). Our evaluations of broom snakeweed control were made near the end of the next growing season (about 12 months after treatment) and indicated that picloram was consistently more effective in killing broom snakeweed, irrespective of treatment year or spray date, than was metsulfuron (Tables 2 and 3). Broom snakeweed mortality was less, though not always significantly, when picloram was sprayed near the same dates in 1998 (average 88\% control) compared to 1997 (average 98\% control). Control with metsulfuron was also higher in 1997 (average 77\%) than 1998 (average 24\%). McDaniel and Duncan (1987) reported in an experiment conducted in central New Mexico that aerial applications of picloram and metsulfuron gave nearly $100 \%$ broom snakeweed control when applied in autumn at the same rates used in this study.

There was little efficacy advantage to application of picloram on earlier spray dates relative to later dates within a treatment year (Tables 2 and 3). Consistent broom snakeweed control with picloram throughout a spray season is an important expectation by aerial applicators and other users of this chemical. Metsulfuron provided relatively higher broom snakeweed control on earlier spray dates than later dates in 1997. However, control with metsulfuron was always poor in 1998 (less than 50\%) and this is a major concern because even a minor presence of broom snakeweed can result in significant grass suppression (McDaniel et al. 1993). In general, broom snakeweed control strategies that eliminate less than $85 \%$ of the mature plants are regarded as unacceptable (Sterling et al. 1999).

\section{Seed Production and Dispersal}

In southern New Mexico, occasional blooms can be found on broom snakeweed throughout the year, but peak flowering generally extends for about 6 to 8 weeks from late summer until a killing frost in autumn (Briede 1990). Broom snakeweed heads usually contain 2 to 7 ray and disk flowers, but only 1 to 3 seeds typically mature from ray florets (Lane 1985). During these experiments, broom snakeweed commenced flowering in early September and ceased flowering by early November when night time air temperatures dropped below freezing (data not shown). A relatively consistent seed supply was collected in traps beneath nonsprayed plants from December through February (Fig. 1). Weather events, such as wind and precipitation, dictated the rate and amount of seed recovered during each 2 week collection period. In this study, we

Table 3. Broom snakeweed control, average seed production, and seedlings established in experimental plots sprayed with 2 herbicides in 1998 at the Chihuahuan Desert Rangeland Research Center, Las Cruces, N.M.

\begin{tabular}{|c|c|c|c|c|c|c|c|c|c|}
\hline \multirow{2}{*}{$\begin{array}{l}\text { Spray } \\
\text { Date }\end{array}$} & \multirow[b]{2}{*}{ Application Timing } & \multicolumn{2}{|c|}{ Plant Control $^{1}$} & \multicolumn{2}{|c|}{ Seed Production } & \multicolumn{2}{|c|}{1999 Seedlings $^{2}$} & \multicolumn{2}{|c|}{2001 Seedlings $^{3}$} \\
\hline & & Picloram & Metsulfuron & Picloram & Metsulfuron & Picloram & Metsulfuron & Picloram & Metsulfuron \\
\hline & & \multicolumn{2}{|c|}{ - } & \multicolumn{2}{|c|}{-no. plant $\left.^{-1}\right)$} & \multicolumn{2}{|c|}{ - $\left(\right.$ no. $\left.\mathrm{m}^{-2}\right)-\cdots$} & \multicolumn{2}{|c|}{ - $\left(\right.$ no. $\left.\mathrm{m}^{-2}\right)-$} \\
\hline 1 Sep. & Early flower - initial seed set & $87 \mathrm{ab}^{4}$ & $8 \mathrm{e}$ & $12 \mathrm{a}$ & $3 a$ & $3.6 \mathrm{a}$ & $0.7 \mathrm{a}$ & 4.3 & 6.5 \\
\hline 15 Sep. & Mid flower - early seed fill & $96 \mathrm{a}$ & $10 \mathrm{e}$ & $125 \mathrm{a}$ & $154 \mathrm{a}$ & $0.0 \mathrm{a}$ & $2.2 \mathrm{a}$ & 4.7 & 2.9 \\
\hline 1 Oct. & Mid flower - mid seed fill & $87 \mathrm{ab}$ & $7 \mathrm{e}$ & $1763 \mathrm{~b}$ & $1776 \mathrm{~b}$ & $3.6 \mathrm{a}$ & $1.8 \mathrm{a}$ & 2.2 & 5.4 \\
\hline 15 Oct. & Late flower - late seed fill & $89 \mathrm{ab}$ & $49 \mathrm{c}$ & $2897 \mathrm{~cd}$ & $1461 \mathrm{~b}$ & $1.1 \mathrm{a}$ & $1.4 \mathrm{a}$ & 3.2 & 2.9 \\
\hline 1 Nov. & Post flower - seed mature & $82 \mathrm{~b}$ & $46 \mathrm{c}$ & $2258 \mathrm{bc}$ & $3658 \mathrm{~d}$ & $0.0 \mathrm{a}$ & $0.0 \mathrm{a}$ & 2.5 & 4.7 \\
\hline 15 Nov. & Post flower - seed dispersal & $84 \mathrm{ab}$ & $27 \mathrm{~d}$ & $2680 \mathrm{c}$ & $3166 \mathrm{~d}$ & $0.7 \mathrm{a}$ & $0.4 \mathrm{a}$ & 4.3 & 6.8 \\
\hline Control & & \multicolumn{2}{|c|}{$0 \mathrm{e}$} & \multicolumn{2}{|c|}{$2861 \mathrm{~cd}$} & \multicolumn{2}{|c|}{$14.7 \mathrm{~b}$} & \multicolumn{2}{|c|}{$4.3 \mathrm{n} / \mathrm{s}$} \\
\hline
\end{tabular}

Plant control evaluated 1 Oct. 1998.

${ }^{2}$ Seedlings counted on 1 July 1999.

${ }^{3}$ Seedlings counted on 1 May 2001.

${ }^{4}$ Means within a category with the same letter are not different $(\mathrm{P}<0.05) ; \mathrm{n} / \mathrm{s}$, not significantly different. 

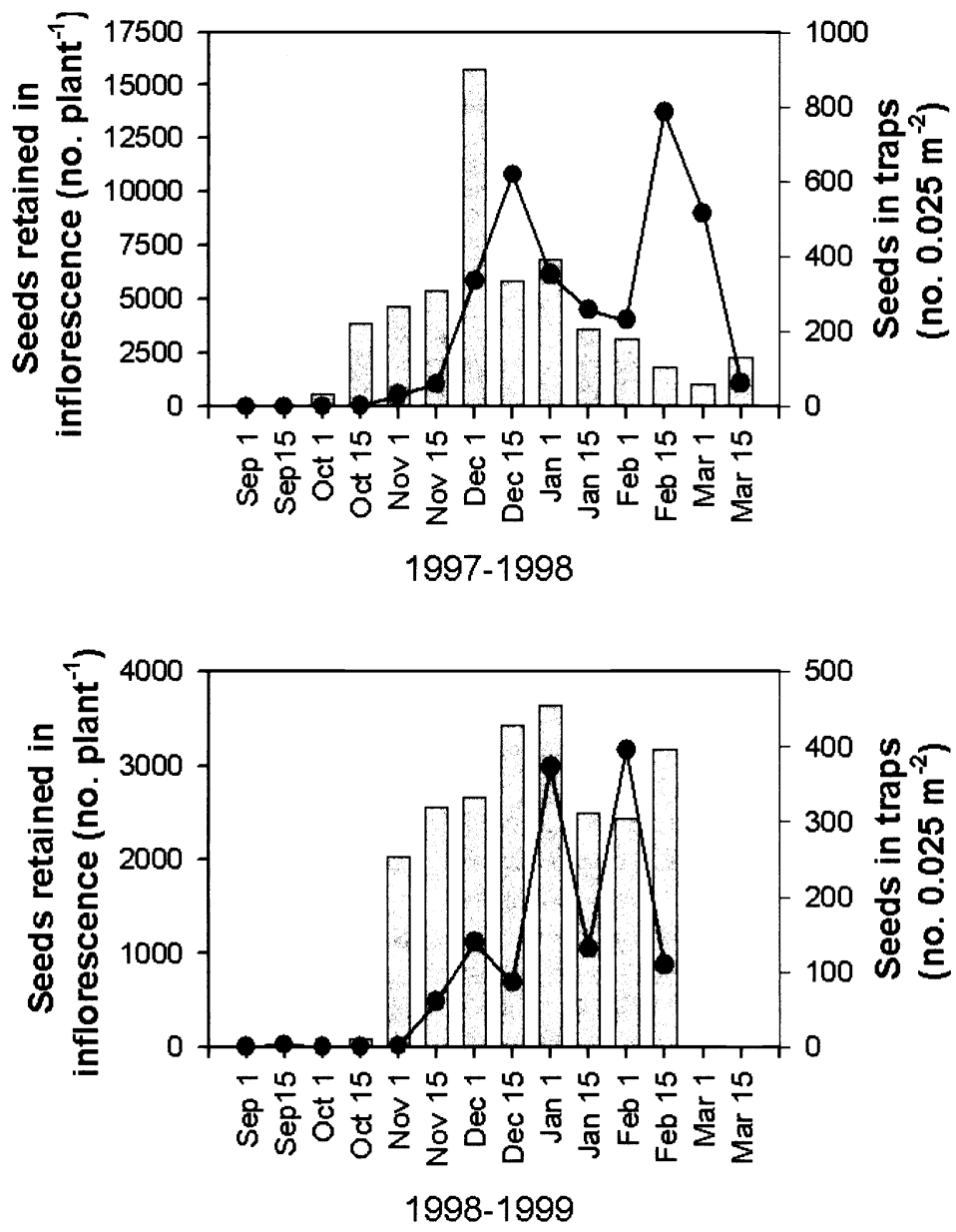

Fig. 1. Average number of broom snakeweed seed recovered from the inflorescence (bar graphs) and from seed traps (line graphs) placed beneath the canopy of nonsprayed plants growing at the Chihuahuan Desert Rangeland Research Center, Las Cruces, N.M. in 1997-1998 and 1998-1999.

stopped collecting seed in March after the majority were dispersed. However, we still found a few seeds on plants until flower parts completely deteriorated in June.

Broom snakeweed seed production can vary greatly from year to year, primarily in response to available soil moisture during flowering (Ragsdale 1969). Under very dry conditions, broom snakeweed typically will not flower, whereas in wetter years, the plant flowers profusely (Pieper and McDaniel 1989). During our study, the average number of seeds per plant counted from the inflorescence of nonsprayed plants was approximately twice as high in 1997 (5,421 seeds per plant) compared to 1998 (2,861 seeds per plant). This difference in seed production between years can largely be attributed to rainfall received during the growing season (April-September) each year. In 1997, growing season rainfall was about $64 \%$ above average whereas precipitation in
1998 was about $30 \%$ below the 30 yr average of $260 \mathrm{~mm}$. A similar yearly difference in broom snakeweed seed production because of rainfall differences during the growing season was reported by Wood et al. (1997) for plants in central New Mexico.

Irrespective of date sprayed in 1997 , there was no significant difference in the average number of mature seed in the inflorescence after applying either picloram or metsulfuron compared to nonsprayed plants (Table 2). Also, the cumulative number of seed dispersed through time from plants sprayed with either picloram or metsulfuron was similar to nonsprayed plants (Fig. 2). In contrast, in 1998 , broom snakeweed plants sprayed with either picloram or metsulfuron on 1 and 15 September produced 99 and $95 \%$ fewer mature seeds per plant, respectively, compared to nonsprayed plants. Plants sprayed with picloram on 1 October produced about $38 \%$ fewer mature seed than nonsprayed plants, whereas plants treated with metsulfuron on 1 and 15 October produced about $43 \%$ less mature seed. Several studies have reported that herbicide applications made at or near anthesis can inhibit seed development and reduce germination (Fawcett and Slice 1978, Anderson 1995, Clay and Griffin 2000). How broom snakeweed seed are damaged by picloram or metsulfuron was not investigated in this study, but research is needed to define how these chemicals impede early seed development. Our examination of seed from nonsprayed plants revealed that the seed coat (testa) was generally soft

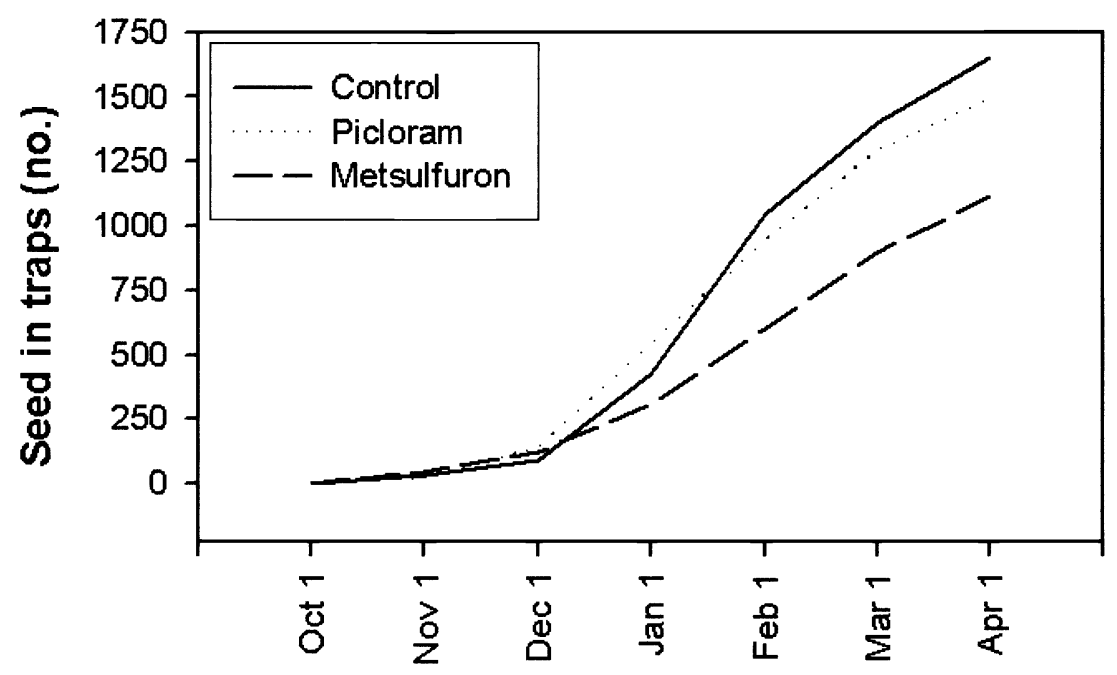

1997-1998 Collection Dates

Fig. 2. Cumulative number of seed dispersed into 5 - by 25 - by $51-\mathrm{cm}$ traps for 22 weeks after spraying on 1 Oct. 1997. Traps were placed beneath 6 broom snakeweed plants per treatment. 


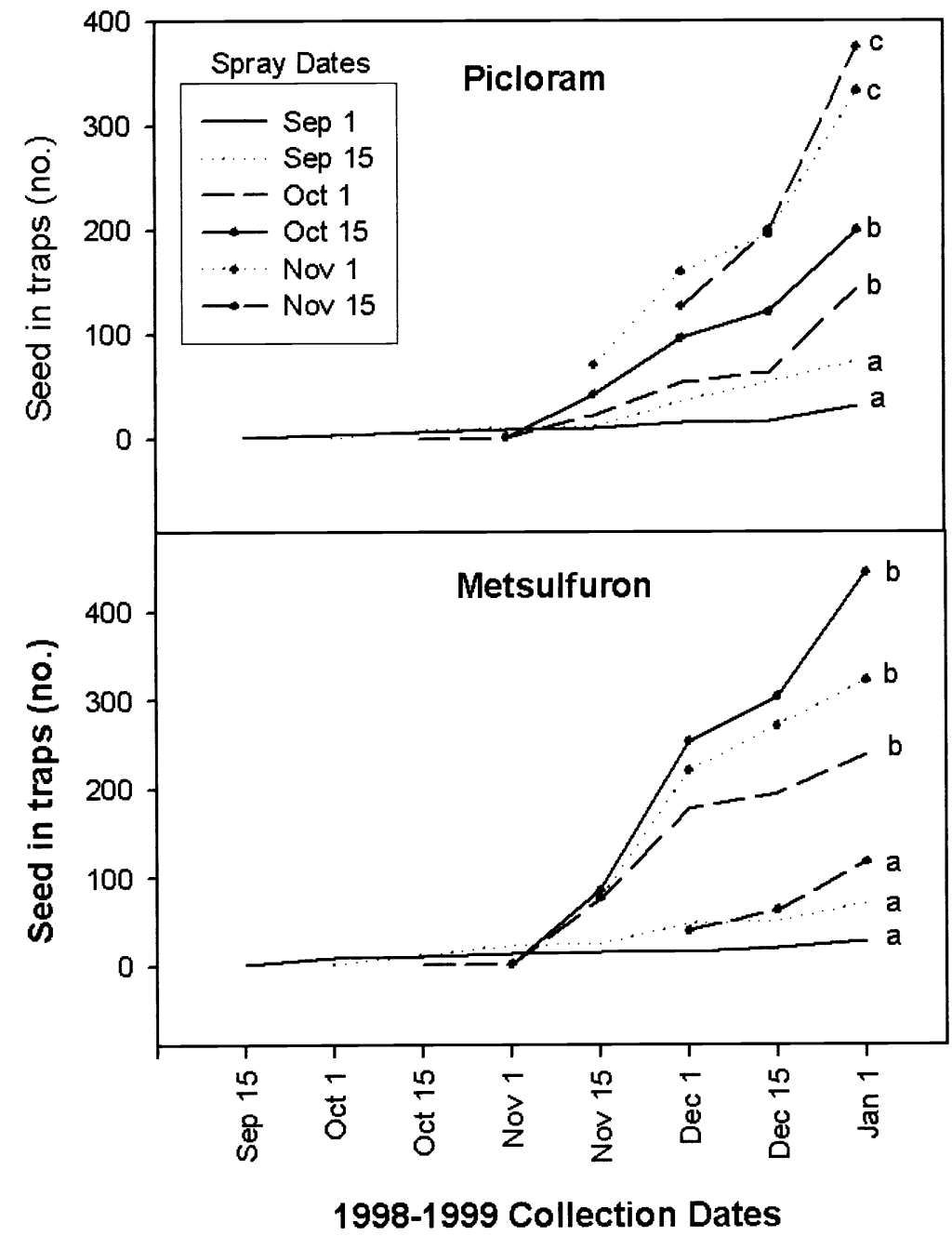

Fig. 3. Cumulative number of seed dispersed into 5- by $25-$ by $51-\mathrm{cm}$ traps after spraying on 6 dates in 1998. Lines by herbicide type followed by a different letter indicate a difference in the total number of seed collected by 1 Jan. 1999. higher for the 1997 (67\%) than the 1998 seedlot (49\%) (Fig. 4). Wood et al. (1997) also reported annual differences in net viability between broom snakeweed seedlots and indicated that seedlot quality was highly influenced by available soil moisture during flowering. In this study, the number of mature seed needed for viability testing was generally not available from the inflorescence until October, and sufficient mature seed from traps was not available until November. Tetrazolium tests indicated little difference in the viability of seed collected from the inflorescence or recovered in traps beneath sprayed and nonsprayed plants after 1 November 1997 (Fig. 5) or 1998 (data not shown). These data agree with Wood et al. (1997) who reported that mature seed retained within the inflorescence or dropped to the surface remained equally viable after seed matured in autumn through the next spring.

In the 1997 experiment, there was no difference in average net seed viability from plants sprayed with picloram or metsulfuron compared to nonsprayed plants on any date except for those sprayed on 1 October (Fig. 6). On 1 October, only mature seed were tested, but the majority of seed taken from inflorescences were actually in the mid or earlier fill stages. Tetrazolium tests revealed net viability to be low (average 22\%) for all seed tested at the time of spraying on 1 October. Two weeks after spraying on 1 October and for the next 20 weeks, seed from metsulfuron treatments had consistently lower net viability (average 26\%) than nonsprayed and (doughy) and embryos remained undeveloped through most of September. We noted that seed in early anthesis remains in a dough stage for 3 to 4 weeks until the testa builds a waxy inner and outer cuticle layer of thickened protective cells that harden around the encased embryo. Because most plants sprayed in early flower with initial to early seed set failed to produce a large quantity of mature seeds, we speculate that a hardened testa provides the protection needed to be impermeable to picloram and metsulfuron. As expected, seed dispersed through time in 1998 was less for plants sprayed on early dates compared to later dates, irrespective of herbicide applied (Fig. 3).

\section{Seed Viability}

The average net viability of seed obtained from the inflorescence of nonsprayed broom snakeweed plants was

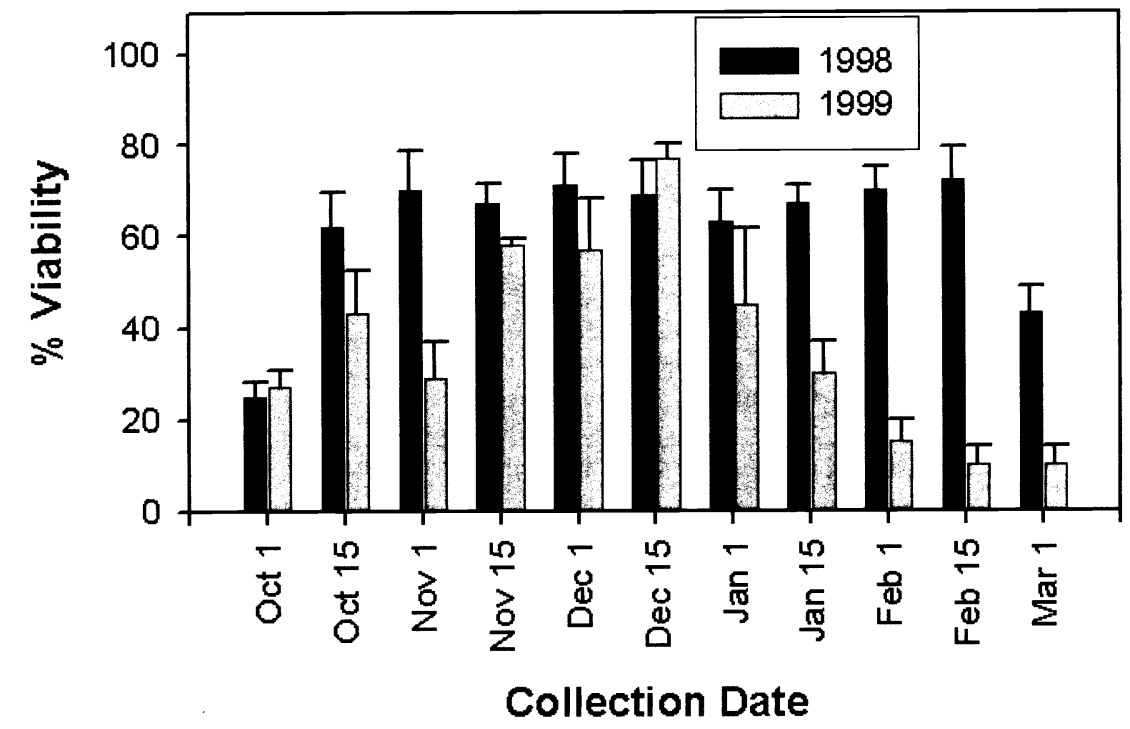

Fig. 4. Percent net viability of seed obtained from nonsprayed broom snakeweed plants on various dates in 1997-1998 and 1998-1999 at the Chihuahuan Desert Rangeland Research Center, Las Cruces, N.M. 


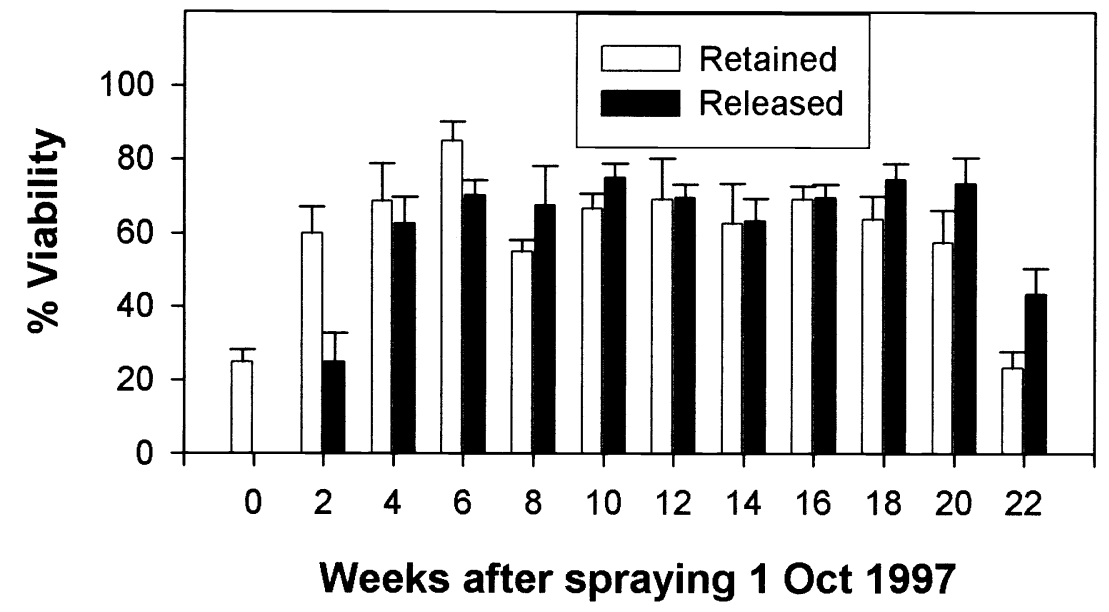

Fig. 5. Percent net viability of nonsprayed broom snakeweed seed retained in the inflorescence or released into traps. Seed collections began on 1 Oct. 1997 and continued every 2 weeks for 22 weeks.

picloram treated plants. Also, net seed viability from picloram treatments (average $45 \%$ ) was less most weeks after spraying on 1 October compared to nonsprayed plants.

In the 1998 experiment, most seed from broom snakeweed plants sprayed with picloram or metsulfuron in September during initial to early fill stages of development did not mature, thus, there was not the supply of seed necessary to give an accurate estimate of net seed viability through time after spraying. Therefore, to obtain a general average estimate of seed viability after the 1 and 15 September 1998 spray dates, it was necessary to combine mature seed from all collection dates. Tetrazolium tests on the composited sam- ples indicated that net seed viability (average $42 \%$ ) was not different from nonsprayed plants, irrespective of spray date or herbicide treatment. There was sufficient seed to determine net viability through time after spraying in October and November. However, TZ tests indicated no significant differences in net seed viability through time by spray date or herbicide treatment compared to nonsprayed plants.

Broom snakeweed seed can potentially germinate any time during the year, but optimal propagation occurs under moist conditions with surface soil temperatures ranging between 10 to $25^{\circ} \mathrm{C}$ (Kruse 1970 ,

\section{Seedling Emergence}

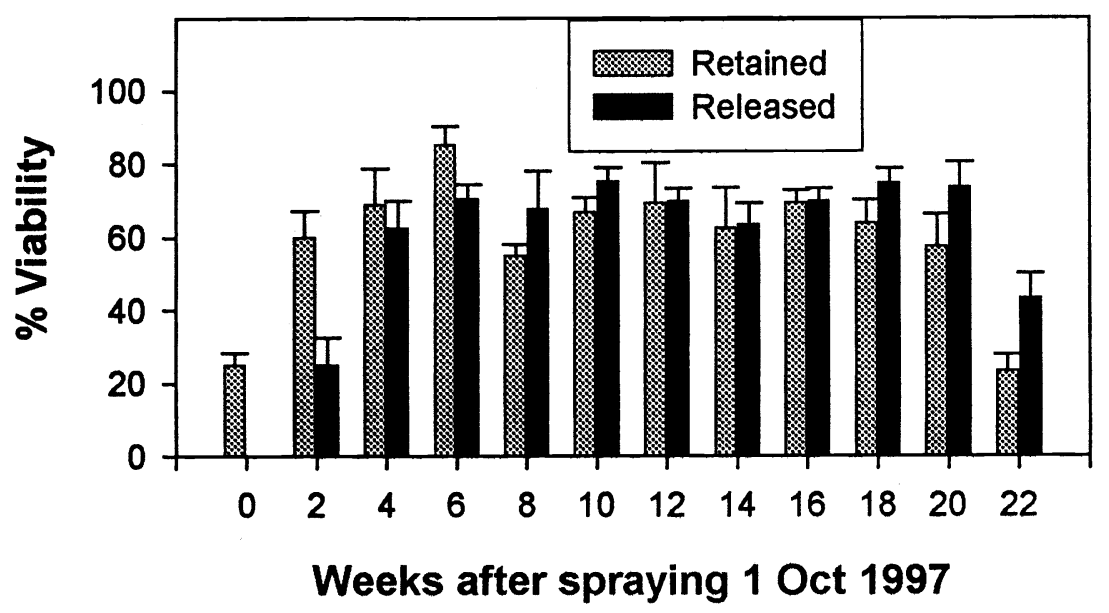

Fig. 6. Percent net viability of broom snakeweed seed collected for 22 weeks after applying herbicides on 1 Oct. 1997 at the Chihuahuan Desert Rangeland Research Center, Las Cruces, N.M.
Mayeux 1980, Mayeux and Leotta 1981, Wood et al. 1997). Long-term vegetation monitoring on the Chihuahuan Desert Rangeland Research Center indicates that above-average rainfall in the first and second quarter of the year (January-June) is most critical for snakeweed propagation (Beck et al. 1999). In general, under southern New Mexico environmental conditions, snakeweed establishment occurs only once or twice a decade (Barnett 1996). Over this 5 year study (1997 to 2001), broom snakeweed seedlings were only noted in herbicide sprayed and nontreated plots in 1999 and 2001. Rainfall was about twice the winter and spring average in 1999 and 2001 , and this is probably what enabled seedlings to establish. When seedlings were counted in 1999, relatively few propagules were noted in the 1998 experimental plots compared to those treated in 1997, irrespective of spray date or herbicide treatment (Tables 2 and 3). Picloram and metsulfuron have soil residual activity that dissipates through time depending on the rate of soil leaching, photo and microbial decomposition, and other processes (Scifres 1980). How long these chemicals remain active in the soil profile is unknown, but we speculate that breakdown of these herbicides within the arid environment of southern New Mexico is slow, requiring 12 months or more. The difference in time after treatment may partially explain why snakeweed germination was retarded the first spring season after 1998 herbicide treatments, and also why seedlings were more common in 1999 in plots sprayed in 1997. In the 1997 experimental plots, seedling numbers in 1999 were equal to or higher in herbicide treated areas, irrespective of spray date, compared to nonsprayed rangeland (Table 2). Conversely, in the 1998 experimental plots, seedling numbers in 1999 were significantly higher in nonsprayed areas than all herbicide plots (Table 3 ). During the 2001 evaluation, there was no difference in the number of broom snakeweed seedlings that emerged in either the 1997 or 1998 experimental plots compared to nonsprayed rangeland (Tables 2 and 3 ).

\section{Management Implications}

Across 2 autumn spray seasons, picloram at a rate of $0.28 \mathrm{~kg}$ a.i. $\mathrm{ha}^{-1}$ provided high and consistent broom snakeweed control when applied from mid flower and early seed development through the plant's post bloom and seed dispersal 
stages. Metsulfuron at a $0.03 \mathrm{~kg}$ a.i. ha rate, however, did not provide consistent control results when applied during this same period. Presently, picloram is the principle herbicide used in New Mexico for broom snakeweed control. The majority of commercial aerial spraying of picloram occurs after broom snakeweed has completed flowering and seed is mature. Results from this study suggest that the current spray season can be widened to include an earlier period in which plants are still in flower.

A major objective of this study was to determine if timed herbicide applications could be used to kill the parent plant and its seed crop, and thus reduce the possibility for future broom snakeweed propagation. Picloram and metsulfuron applications made in the 1997 experiment did not lower seed production because spraying did not begin until most seed in the inflorescence had already reached physiological maturity. Two spring seasons after the 1997 treatments, broom snakeweed seedlings were equal or more abundant in all experimental spray plots than in nonsprayed areas, indicating that the herbicides did not impede future propagation. In the 1998 experiment, herbicide applications made in September when broom snakeweed was in flower and early seed development resulted in a near elimination of seed production. The first spring after the 1998 spraying, environmental conditions were suitable for broom snakeweed germination, but few seedlings established in sprayed plots. However, 3 spring seasons after spraying in 1998, seedling numbers were equal in all herbicide and nonsprayed experimental plots, irrespective of spray date. Thus, results from this study were inconclusive for determining if timed herbicide applications could be used to destroy both the parent plant and its seed crop and thereby cause a reduction in future broom snakeweed propagation.

\section{Literature Cited}

Anderson, L. 1995. Effects of dose and application timing on seed production of three weed species treated with MCPA or tribenuron-methyl. Weed Res. 35:67-45.

Barnett, B. L. 1996. Influence of winter precipitation on broom snakeweed establishment in the Chihuahuan Desert. M.S. Thesis, New Mexico State Univ., Las Cruces, N.M.

Beck, R. F., M. Nsinamwa, R. Santos, and R. D. Pieper. 1999. Dynamics of Gutierrezia sarothrae with drought and grazing, $\mathrm{p}$. 502-504. In: D. Eldridge and D. Freudenberger (eds.). Proc. of the VI Intern. Rangeland Congress, Vol. 1, Townsville, Australia.
Briede, J. W. 1990. The physiological ecology of Gutierrezia sarothrae (Pursh) Rusby in the Chihuahuan Desert of Southern New Mexico. Ph.D. Diss., New Mexico State Univ., Las Cruces, N.M.

Clay, P. A. and J. L. Griffin. 2000. Weed seed production and seedling emergence responses to late-season glyphosate applications. Weed Sci. 48:481-486.

Duncan, K. W. and K. C. McDaniel. 1991. Chemical weed and brush control guide for New Mexico rangelands. New Mexico Coop. Exten. Serv. 400B-17.

Fawcett, R. S. and F. W. Slice. 1978. Effects of 2,4-D and dalapon on weed seed production and dormancy. Weed Sci. 26:543-547.

Kruse, W. H. 1970. Temperature and moisture stress affect germination of Gutierrezia sarothrae. J. Range Manage. 23:143-144.

Lane, M. A. 1985. Taxonomy of Gutierrezia sarothrae (Compositae: Astereae) in North America. Syst. Bot. 10:7-28.

Mayeux, H. S. 1980. Effects of soil texture and seed placement on emergence of four subshrubs. Weed Sci. 31:380-384.

Mayeux, H. S. and L. Leotta. 1981. Germination of broom snakeweed and threadleaf snakeweed seed. Weed Sci. 31:380-384.

McDaniel, K. C. 1989. Use of herbicides in snakeweed management, p.85-100. In: E. W. Huddleston and R. D. Pieper (eds.). Snakeweed: Problems and Perspectives. New Mexico State Univ. Agr. Exp. Sta. Bull. 751. Las Cruces, N.M.

McDaniel, K. C. and K. W. Duncan. 1987. Broom snakeweed control with picloram and metsulfuron. Weed Sci. 35:837-841.

McDaniel, K. C., D.B. Carroll, and C. R. Hart. 2000. Broom snakeweed establishment following fire and herbicide treatments. J. Range Manage. 53:239-245.

McDaniel, K. C., L. A. Torell, and J. W. Bain. 1993. Overstory-understory relationships for broom snakeweed - blue grama grasslands. J. Range Manage. 46:506-511.

Pieper, R. D. and K. C. McDaniel. 1989. Ecology and management of broom snakeweed, p. 1-12. In: E. W. Hudleston and R. D. Pieper (eds.). Snakeweed: Problems and Perspectives. New Mexico State Univ. Agr. Exp. Sta. Bull. 751. Las Cruces, N.M.

Ragsdale, B. J. 1969. Ecological and phenological characteristics of perennial broomweed. Ph.D. Diss., Texas A\& M Univ., College Station, Tex.

SAS Institute Inc. 1989. SAS/SAT users guide, version 6 , 4th ed., vol. 2. SAS Institute Inc., Cary, N.C.

Scifres, C. J. 1980. Brush Management. Principles and practices for Texas and the southwest. Texas A \& M Univ. Press, College Station, Tex.

Solbrig, O. T. 1960. Cytotaxonomic and evolutionary studies in the North American species of Gutierrezia (Compositae). Contrib. Gray Herb. 188:1-61.

Sosebee, R. E. 1985. Timing - The key to herbicidal control of broom snakeweed. Texas Tech Manage. Note 6, Lubbock, Tex.
Sosebee, R. E. 2000. Timing-the key to successful brush and weed control, p. 215-225. In: Proc. Rangeland Weed and Brush Management - The Next Millennium. Oct 19-21, 2000. Texas A\&M Research and Extension Center, San Angelo, Tex.

Sosebee, R. E. and B. E. Dahl. 1991. Timing of herbicide application for effective weed control: A plant's ability to respond, $\mathrm{p}$. 115-126. In: L. F. James, J. O. Evans, M. H. Ralphs, and R. D. Childs (eds.), Noxious Range Weeds. Westview Press, Boulder, Colo.

Sterling, T. M., D. C. Thompson, and K. C. McDaniel. 1999. Snakeweeds, p. 323-334. In: R. L. Sheley and J. K. Petroff (eds.), Biology and Management of Noxious Rangeland Weeds. Oregon State Univ. Press, Corvallis, Ore.

Strickland, J. R., L.F. Gulimo-Klein, T.T. Ross, S. Slate, M. K. Petersen, T. May, and J. B. Taylor. 1998. Effects of nutrient supplementation in beef cows of poor body condition fed snakeweed (Gutierrezia spp.). Vet. Hum. Tox. 40:278-284

Tetrazolium Committee of Association of Official Seed Analysts. 1970. Tetrazolium testing, p. 62. In: D. F. Grabe (ed.), Tetrazolium Testing, Handbook for Agricultural Seed No. 29.

Thill, D. C., D. L. Zamora, and D. L. Kambitsch. 1985. Germination and viability of common crupina (Crupina vulgaris) achenes buried in the field. Weed Sci. 33:344-348.

Torell, L. A., K. C. McDaniel, and K. Williams. 1992. Estimating the life of shortlived, cyclic weeds with Markov processes. Weed Tech. 6:62-67.

Torell, L. A., K. Williams, and K. C. McDaniel. 1989. Economics of broom snakeweed control, p. 113-138. In: E. W Huddleston and R. D. Pieper (eds.), Snakeweed: Problems and Perspectives. New Mexico State Univ. Agr. Exp. Sta. Bull. 751, Las Cruces, N.M.

Townsend, C. L. 1995. The success and treatment life of commercial chemical snakeweed control projects in New Mexico. M.S. Thesis, New Mexico State Univ., Las Cruces, N.M.

U. S. Department of Agriculture Soil Conservation Service. 1980. Soil survey of Dona Ana County, New Mexico. U.S. Govt. Printing Office, Washington, D.C.

Williams, K. E. 1990. Treatment life uncertainty and the economic decision to control broom snakeweed. M.S. Thesis, New Mexico State Univ., Las Cruces, N.M.

Wood, B. L., K. C. McDaniel, and D. Clason. 1997. Broom snakeweed dispersal, viability, and germination. Weed Sci. 45:77-84. 